\title{
Ingredients in Children's Fluoridated Toothpaste: A Literature Review
}

\author{
Corey H. Basch ${ }^{1} \&$ William D. Kernan ${ }^{1}$ \\ ${ }^{1}$ Department of Public Health, William Paterson University, Wayne, New Jersey, United States of America \\ Correspondence: Corey H. Basch, Department of Public Health, William Paterson University, Wayne, New \\ Jersey 07470, United States of America. Tel: 1-973-720-2603. E-mail: baschc@wpunj.edu
}

Received: May 1, 2016 Accepted: June 8, 2016 Online Published: July 11, 2016

doi:10.5539/gjhs.v9n3p1 URL: http://dx.doi.org/10.5539/gjhs.v9n3p1

\begin{abstract}
Children's fluoridated toothpastes are supplemented with ingredients intended to increase appeal. A comprehensive list of children's toothpastes and their ingredients was compiled from nine pharmacies in New York City. A broad literature review was then conducted to describe the purpose of the ingredient and the known contamination risks associated with chronic consumption of each ingredient. The final sample size comprised 26 children's toothpastes and 45 unique ingredients. The purpose and known contamination risks of the 45 identified ingredients were documented. A proportion of ingredients $(28.9 \%[\mathrm{n}=13])$ were found to be both unnecessary to improving the oral health of children and solely used to increase their appeal. Of this list of unnecessary ingredients, $69.2 \%(\mathrm{n}=9)$ were shown to have contamination risks associated with chronic consumption, including enamel demineralization. The authors recommend that toothpaste manufacturing practices be limited to include only ingredients that are necessary for improved oral health and care and only using natural flavorings when needed.
\end{abstract}

Keywords: toothpaste, toxicology, oral health, children

\section{Introduction}

Toothpaste has been used for hundreds of years. It first appeared in a tube in the 1800's and its ability to curb dental disease was lacking (Ramirez, 1990). Still, many formulas were created and there was competition to increase toothpaste use and sales (Ramirez, 1990). In a quest to see toothpaste use become more pervasive, a successful advertiser, Claude Hopkins set off to find a "trigger that would justify the toothpaste's daily use (Duhigg, 2012 p. 34)." This trigger turned out to be daily use to remove a film on teeth, a step in making one more attractive. The appeal of this was alluring, and toothpaste use is now normative. With many toothpastes available for purchase, companies set their sights on increasing marketing tactics to in turn increase profits. Therapeutically speaking, fluoride stands alone among the ingredients list as having the benefit of fighting dental decay (Ramirez, 1990).

Children's fluoridated toothpastes are supplemented with a number of unnecessary and potentially toxic ingredients that are utilized to increase the appeal of toothpaste among young children. One study found that marketing tactics for children's toothpaste include depicting pictures of fruit on the front of toothpaste tubes as well as use of animated characters, and attractive flavorings that mirror common food items (Basch \& Rajan, 2014). In some cases, toothpaste tubes even depicted a full swirl of toothpaste, and image that is in contradiction with the amount of toothpaste recommended to be used by children (Basch \& Rajan, 2014). While perhaps not the intent, these depictions could lead consumers (both adults and children) to believe that toothpaste is safe, or even intended to be consumed as if it were a food product. Studies have shown that overconsumption of fluoridated toothpastes among children is associated with health risks such as fluorosis, which causes changes in tooth enamel ranging from spots to stains to deep pitting depending on the severity (Centers for Disease Control [CDC], 2013).

There is an existing research base that focuses on the role of active ingredients in toothpaste to determine their efficacy on reducing dental caries and controlling the viability of bacteria present in dental plaque (Erdal \& Buchanan, 2005; Afflitto, Fakhry-Smith, \& Gaffar, 1989; Kraivaphan, Amornchat, \& Triratana, 2013). However, while fluorosis results from the overconsumption of fluoride, possible risks associated with the chronic consumption of other ingredients present in children's fluoridated toothpaste have not been identified. The addition of unnecessary and potentially toxic ingredients (such as sweeteners, artificial colorings, flavorings and 
other additives that facilitate the composition of toothpaste in appearing more like a food product) further increases the likelihood that children will consume more toothpaste than is recommended by the American Dental Association (ADA). It should also be noted that the presence of these unnecessary ingredients do not contribute to a child's improved oral health (Center for Science in the Public Interest [CSPI], 2012; Food and Drug Administration [FDA], 2010).

Currently no studies exist that systematically identify the presence of unnecessary and potentially toxic ingredients in children's toothpastes and use available peer-reviewed literature to describe known contamination risks. Indeed, a recent publication stated that with regard to food products, most individuals are not aware about the source and/or possible risks associated with particular ingredients (Nicole, 2013). The authors estimate that the same holds true for cosmetic and hygiene products. In the United States, for example, the US Food and Drug Administration (FDA) regulates the safety and efficacy of fluoridated toothpaste as used during brushing, however the intent is never for toothpaste to be consumed. Previous research has suggested that young children may swallow up to half of the toothpaste on their brush during any given instance; a significant amount (Rock, 1994). Toothpaste advertised as a food-like substance, used multiple times a day, and often swallowed by young children, poses risks for bioaccumulation (Delorenzo et al., 2008; Ethier et al., 2012). The authors therefore collected data to identify the presence of potentially toxic ingredients in children's toothpaste and subsequently conducted a literature review to describe the purpose of the ingredient as well as the known contamination risks associated with chronic overconsumption. Recommendations for alternatives to promoting positive and safe oral care practices are provided and the crucial role of dental hygienists, health educators, and public health professionals is emphasized.

\section{Methods}

Ancillary to another study, ingredients from children's fluoridated toothpastes being sold at drug stores and pharmacies in New York City (NYC) were coded (Basch \& Rajan, 2014). The coder visited locations until a comprehensive and exhaustive list of children's toothpaste products was compiled. A coding sheet was created to record the amount of fluoride present in each toothpaste product, as well as all additional ingredients. The coder (CB) recorded ingredient information for each toothpaste in the study's sample. It should be noted that the study's sample size represents unique toothpaste products based on the packaging and brand.

A thorough review of current peer-reviewed literature was subsequently conducted to identify the purpose, known contamination risks, and risk for bioaccumulation of each ingredient. The primary search engine utilized was PubMed, however, both Google Scholar and Microsoft Academic Search were used to ensure that no publication was missed. It should be noted that in instances where there were gaps in current peer-review literature regarding ingredient toxicology, Material Safety Data Sheets were consulted to examine ingredient toxicology.

"Necessary" ingredients were defined by the authors as those ingredients used specifically to increase the quality of children's oral health and/or contribute to the production of toothpaste as a paste. "Unnecessary" ingredients were defined by the authors as those ingredients that do not contribute to a child's improved oral health and/or ingredients that help toothpaste taste like a food product. While the authors acknowledge that isolated incidences of toothpaste consumption can and do occur, this study is concerned with chronic toothpaste consumption among young children. Specifically, chronic consumption of toothpaste among children was defined by the authors as swallowing any amount of toothpaste, multiple times a week and for an extended period of time (greater than one year). Finally, and as emphasized earlier, while the ADA recommends that a pea-sized amount of toothpaste be used for brushing, no amount of toothpaste is ever intended to be swallowed (ADA, 2013a). This research was deemed exempt by the Institutional Review Board at William Paterson University.

\section{Results}

The study's sample size comprised 26 children's fluoridated toothpastes, coded from nine stores in NYC. The sample represented well-known toothpaste companies. All toothpastes included in the sample were fluoridated, with sodium fluoride amounts ranging from $0.13 \%-0.243 \%$. Nearly the entire sample $(92.3 \%[\mathrm{n}=24])$ stated they were flavored toothpastes, with sweet and appealing flavors ranging from strawberry to bubblegum. Table 1 lists the observed unnecessary ingredients among this sample of children's toothpastes, their purpose, and known contamination risks. Table 2 lists the observed necessary ingredients among this sample of children's toothpastes, their purpose, and known contamination risks. Risk for bioaccumulation is indicated in each table, where appropriate.

The authors identified 45 unique ingredients across the entire sample. A comprehensive review of the purpose and toxicology associated with each ingredient demonstrated that $75.6 \%(n=34)$ of these ingredients have 
specific and known contamination risks associated with chronic consumption and two of these ingredients have documented risks for bioaccumulation. While $71.1 \%(\mathrm{n}=32)$ of the ingredients identified were defined by the authors as those ingredients used specifically to increase the quality of oral health and/or contribute to the production of toothpaste as a paste, the remaining $28.9 \%(\mathrm{n}=13)$ ingredients were identified as being unnecessary to improving the oral health of the consumers (Table 1).

Table 1. Purpose and known contamination risks of unnecessary toothpaste ingredients

\begin{tabular}{|c|c|c|c|}
\hline Ingredient & Ingredient & Purpose & Known Contamination Risks \\
\hline \multirow{3}{*}{ Sweeteners } & $\begin{array}{l}\text { Sodium } \\
\text { Saccharin }\end{array}$ & $\begin{array}{l}\text { An artificial sweetener (Fitch \& } \\
\text { Keim, 2012). }\end{array}$ & $\begin{array}{l}\text { Findings are mixed; the use of sodium saccharin as a } \\
\text { sweetener is considered safe for consumption (Fitch \& } \\
\text { Keim, 2012), but recent research suggests it contributes to } \\
\text { enamel demineralization (Giacamam, Campos, Munoz- } \\
\text { Sandoval, \& Castro, 2013). }\end{array}$ \\
\hline & Sorbitol & $\begin{array}{l}\text { A substitute for sugar used as a } \\
\text { sweetening agent (Fitch \& Keim, } \\
\text { 2012). }\end{array}$ & $\begin{array}{l}\text { The malabsorption of sorbitol has been shown to cause } \\
\text { abdominal discomfort, as well as diarrhea (Fernandez- } \\
\text { Banares, Esteve, \& Viver, 2009). }\end{array}$ \\
\hline & Sucralose & $\begin{array}{l}\text { A nonnutritive sweetener (Fitch \& } \\
\text { Keim, 2012). }\end{array}$ & $\begin{array}{l}\text { Recent findings suggest that sucralose is not biologically } \\
\text { inert (Soffritti et al., 2016). }\end{array}$ \\
\hline \multirow{5}{*}{$\begin{array}{l}\text { Artificial } \\
\text { Colorings }\end{array}$} & $\begin{array}{l}\text { FD\&C Blue } 1 \\
\text { Lake }\end{array}$ & $\begin{array}{l}\text { Functions as a coloring agent } \\
\text { (Kobylewski \& Jacobson, 2010). }\end{array}$ & $\begin{array}{l}\text { Some research suggests that exposure to this coloring } \\
\text { agent results in allergic reactions and the inhibition of } \\
\text { nerve-cell development (Kobylewski \& Jacobson, 2010). }\end{array}$ \\
\hline & $\begin{array}{l}\text { D\&C } \\
\text { Lake }\end{array}$ & $\begin{array}{l}\text { Functions as a coloring agent } \\
\text { (Environmental Working Group, } \\
\text { 2013). }\end{array}$ & $\begin{array}{l}\text { Bioaccumulation of D\&C Red } 30 \text { Lake over time has been } \\
\text { shown to lead to organ toxicity (Environmental Working } \\
\text { Group, 2013). }\end{array}$ \\
\hline & D\&C Red 33 & $\begin{array}{l}\text { Functions as a coloring agent } \\
\text { (Science Lab, 2013c). }\end{array}$ & $\begin{array}{l}\text { D\&C Red } 33 \text { is known to cause irritation of the skin, eyes, } \\
\text { and respiratory tract, as well as skin discoloration } \\
\text { (Science Lab, 2013c). }\end{array}$ \\
\hline & D\&C Red 28 & $\begin{array}{l}\text { Functions as a coloring agent } \\
\text { (National Institute of Environmental } \\
\text { Health Sciences [NIEHS], 2000). }\end{array}$ & $\begin{array}{l}\text { Toxicology data demonstrate that this dye contributes to } \\
\text { genetic damage via the formation of free radicals (NIEHS, } \\
\text { 2000). }\end{array}$ \\
\hline & Red 40 & $\begin{array}{l}\text { Functions as a coloring agent } \\
\text { (Kobylewski \& Jacobson, 2010). }\end{array}$ & $\begin{array}{l}\text { Red } 40 \text { is believed to be a carcinogen and known to cause } \\
\text { allergic reactions (Kobylewski \& Jacobson, 2010). }\end{array}$ \\
\hline $\begin{array}{l}\text { Foam and } \\
\text { Flavor } \\
\text { Booster }\end{array}$ & $\begin{array}{l}\text { Cocamidopropyl } \\
\text { Betaine }\end{array}$ & $\begin{array}{l}\text { This substance is added as a foaming } \\
\text { agent (Moreau \& Kaplan, 2013) }\end{array}$ & $\begin{array}{l}\text { Though relatively rare, research indicates that } \\
\text { cocamidopropyl betaine may be a contact allergen } \\
\text { (Schnuch, Lessmann, Geier, \& Uter, 2011; Jacob \& } \\
\text { Amini, 2008) }\end{array}$ \\
\hline \multirow{4}{*}{ Flavorings } & Flavor & $\begin{array}{l}\text { Functions as a flavoring agent } \\
\text { (Sainio \& Kanerva, 1995). }\end{array}$ & $\begin{array}{l}\text { This substance has been shown to cause allergic reactions, } \\
\text { including inflammation of the mouth and lips and } \\
\text { gingivitis (Sainio \& Kanerva, 1995). }\end{array}$ \\
\hline & Menthol & $\begin{array}{l}\text { Functions as a flavoring and scent } \\
\text { for toothpaste (International } \\
\text { Programme on Chemical Safety } \\
\text { [IPCS], 1999). }\end{array}$ & No known contamination risks (IPCS, 1999) \\
\hline & Natural Flavors & $\begin{array}{l}\text { Encompass a range of flavorings } \\
\text { derived from herbs and fruits and } \\
\text { together function as a flavoring for } \\
\text { toothpaste (Schrankel, 2004; Smith } \\
\text { et al., 2005). }\end{array}$ & $\begin{array}{l}\text { No known contamination risks (Schrankel, 2004; Smith et } \\
\text { al., 2005). }\end{array}$ \\
\hline & Strawberry Juice & $\begin{array}{l}\text { Functions as a natural flavoring for } \\
\text { toothpaste. }\end{array}$ & $\begin{array}{l}\text { No known contamination risks (Schrankel, 2004; } \\
\text { Griffiths, 2005). }\end{array}$ \\
\hline
\end{tabular}


More concerning, these latter ingredients are specifically and solely used to increase their appeal to young children and the majority of these ingredients $(69.2 \%[\mathrm{n}=9])$ were found to have known contamination risks. These ingredients are as follows: sweeteners (sodium saccharin and sorbitol), artificial colorings (Blue 1 Lake, D\&C Red 30 Lake, D\&C Red 33, D\&C Red 28, Red 40), a foam and flavor booster (cocamidopropyl betaine), and a subset of flavoring agents distinguished on the toothpaste labeling only as "flavor". Identified health risks associated with these ingredients were found to range from enamel demineralization to abdominal discomfort. Among the entire sample of children's toothpastes, $80.8 \%(\mathrm{n}=21)$ contained at least one of and $50.0 \%(\mathrm{n}=13)$ contained at least two of these unnecessary ingredients with identified known contamination risks. The risks of fluoride overconsumption have been previously well documented (Erdal \& Buchanan, 2005; Heifetz \& Horowitz, 1986). This study expands on this knowledge base by also clearly identifying the risks associated with the additional and necessary ingredients currently found in children's toothpaste products (Table 2).

Table 2. Purpose and Known Contamination Risks of Necessary Toothpaste Ingredients

\begin{tabular}{|c|c|c|}
\hline Ingredient & Purpose & Known Contamination Risks \\
\hline \multicolumn{3}{|l|}{ Active Ingredients } \\
\hline Sodium Fluoride & $\begin{array}{l}\text { Fights the formation of dental caries, } \\
\text { helps with teeth whitening, and } \\
\text { decreases mouth odors (Ten Cate, 2013). }\end{array}$ & $\begin{array}{l}\text { Excess ingestion of sodium fluoride has been linked } \\
\text { with dehydration, as well as the possibility of dental and } \\
\text { skeletal fluorosis (Erdal \& Buchanan, 2005; Heifetz \& } \\
\text { Horowitz, 1986). }\end{array}$ \\
\hline Triclosan & $\begin{array}{l}\text { Primarily aids in the prevention of gum } \\
\text { disease (gingivitis) (Food and Drug } \\
\text { Administration [FDA], 2013; Chen et al., } \\
\text { 2012). }\end{array}$ & $\begin{array}{l}\text { Triclosan may affect the formation of thyroid hormone } \\
\text { (FDA, 2013; Chen et al., 2012; Johnson et al, 2016). }\end{array}$ \\
\hline \multicolumn{3}{|l|}{ Synthetic Polymers } \\
\hline PEG-8 & $\begin{array}{l}\text { Used to stabilize and keep cosmetics } \\
\text { (such as toothpaste) from drying out; } \\
\text { also helps to control plaque buildup } \\
\text { (Fruijtier-Pölloth, 2005). }\end{array}$ & $\begin{array}{l}\text { Research suggests that PEG- } 8 \text { may result in delayed } \\
\text { allergic reactions (Wenande, Skov, Mosbech, Poulsen, } \\
\text { \& Garvey, 2013). }\end{array}$ \\
\hline PEG-12 & $\begin{array}{l}\text { Used to stabilize and keep toothpaste } \\
\text { from drying out; also helps to control } \\
\text { plaque buildup (Fruijtier-Pölloth, 2005). }\end{array}$ & $\begin{array}{l}\text { No known contamination risks (Wenande, Skov, } \\
\text { Mosbech, Poulsen, \& Garvey, 2013). }\end{array}$ \\
\hline PEG-32 & $\begin{array}{l}\text { Used to stabilize and keep the toothpaste } \\
\text { from drying out; also thickens the } \\
\text { toothpaste to keep the ingredients from } \\
\text { separating (Fruijtier-Pölloth, 2005). }\end{array}$ & $\begin{array}{l}\text { No known contamination risks (Wenande, Skov, } \\
\text { Mosbech, Poulsen, \& Garvey, 2013). }\end{array}$ \\
\hline PEG-1450 & $\begin{array}{l}\text { Used as surfactant, solvent, and } \\
\text { plasticizer (Skaare, Kjærheim, Barkvoll, } \\
\text { \& Rølla, 1997) }\end{array}$ & $\begin{array}{l}\text { This substance could cause mild irritation to the skin } \\
\text { and eyes (Science Lab, 2013d). }\end{array}$ \\
\hline PVM/MA Copolymer & $\begin{array}{l}\text { Used as a stabilizer and a binder; also } \\
\text { helps to fight bacteria (Podariu, Galscan, } \\
\text { \& Rosianu, 2009). }\end{array}$ & $\begin{array}{l}\text { No known contamination risks (Podariu, Galscan, \& } \\
\text { Rosianu, 2009; DiLucco et al., 1989). }\end{array}$ \\
\hline Carbomer & $\begin{array}{l}\text { Used to control the flow of products } \\
\text { (such as toothpaste) and keeps the } \\
\text { ingredients of the toothpaste from } \\
\text { separating (Luo, Wilber, \& Guo, 2004). }\end{array}$ & $\begin{array}{l}\text { Though rare, research has suggested that carbomer may } \\
\text { be a contact (skin) allergen (Vie, Pons-Guiraud, Dupuy, } \\
\text { \& Maibach, 1991). }\end{array}$ \\
\hline \multicolumn{3}{|l|}{ Emulsifiers } \\
\hline $\begin{array}{l}\text { Sodium } \\
\text { Sulfate }\end{array}$ & $\begin{array}{l}\text { Makes toothpastes thicker, and acts as a } \\
\text { foaming agent while brushing (ADA, } \\
2013 b \text { ). }\end{array}$ & $\begin{array}{l}\text { This substance could cause irritation to the skin and } \\
\text { eyes, as well as gastrointestinal irritation (Wilhelm, } \\
\text { Surber, \& Maibach, 1991; Blondeel, Oleffe, \& Achten, } \\
\text { 1978). }\end{array}$ \\
\hline
\end{tabular}




\begin{tabular}{ll}
\hline $\begin{array}{l}\text { Sodium } \\
\text { Carboxymethyl } \\
\text { Cellulose }\end{array}$ & $\begin{array}{l}\text { Used as a toothpaste emulsion stabilizer } \\
\text { (CSPI, 2012). }\end{array}$ \\
Poloxamer 407 & $\begin{array}{l}\text { Aids in the process of dissolving other } \\
\text { ingredients to create an emulsion } \\
\text { (Garala, Joshi, Shah, Ramkishan, \& }\end{array}$ \\
& Patel, 2013; Bhardwaj \& Bhardwaj, \\
& 2011).
\end{tabular}

Tetrasodium Pyrophosphate

Sodium

Hexametaphosphate
Used to prevent plaque buildup by reducing the amount of calcium and magnesium from one's saliva during brushing (Llena, Forner, \& Vento, 2009; Winston, Fiedler, Schiff, \& Baker, 2007).

Aids in extrinsic stain removal (He et al., 2007).

$\begin{array}{ll}\text { Buffering Agents } & \\ \text { DiSodium } & \begin{array}{l}\text { Helps to prevent plaque buildup by } \\ \text { Pyrophosphate }\end{array} \\ & \begin{array}{l}\text { reducing the amount of calcium and } \\ \text { magnesium from saliva (DeLattre, } \\ \text { 1999). }\end{array}\end{array}$

Preservatives

Propylparaben

Sodium Benzoate

Sodium

Methylparaben

Used as a preserving agent (Golden, Gandy, \& Vollmer, 2005).

Sodium Phosphate

Used as a $\mathrm{pH}$ stabilizer and buffering agent (Duke, Reading, \& Jackson, 1988).

Center for Biotechnology Information, 2013).

Used as a preserving agent (Nair, 2000).
No known contamination risks (CSPI, 2012).

This substance could cause irritation to the eyes and renal issues (Spectrum Laboratory, 2007; Dumortier, Grossiord, Agnely, \& Chaumeil, 2006). In animal studies, when given parentally, it caused hyperlipidaemia and engorgement of Kupffer cells (Warren, Benseler, Cogger, Bertolino, Le, \& Couter, 2011).

This substance could cause irritation of the nose, skin, eyes, throat, and respiratory passages (CDC, 2011).

If ingested, excess consumption of this substance could cause irritation of the skin and eyes; respiratory tract irritation; and vomiting, nausea, and diarrhea; lethargy (Lanigan, 2000).

Exposure to disodium pyrophosphate could cause severe skin irritation; research suggests that high levels of exposure to this substance may also be hazardous to blood and lungs (Lewis, 1996).

Research suggests that propylparaben may be hazardous to one's lungs and could cause skin irritation (Soni, Burdock, Taylor, \& Greenberg, 2001).

Excess consumption of this substance could decrease the ability of the immune system to function properly and also cause other irritations (Science Lab, 2013e; Munoz, Bellido, Moyano, Alvarez, \& Fonseca, 1996).

Excess consumption of this substance includes an increased risk of male infertility, breast cancer, skin cancer (Golden, Gandy, \& Vollmer, 2005; Boberg, Taxvig, Christiansen, \& Haas, 2010).

Acute exposure to sodium phosphate can lead to skin and eye irritation; the chronic effects of exposure to sodium phosphate, however, are not known (Science Lab, 2013f).

Thickening Agent

Carrageenan

Used as a toothpaste thickener (CSPI, 2012).

Cellulose Gum

Used as a toothpaste thickener (CSPI, 2012).

Xanthan Gum

Used as a toothpaste thickener and stabilizer (Becker, Katzen, Puhler, \& Ielpi, 1998).
Side effects associated with consumption of this substance include gastrointestinal issues (Tache, Peiffer, Millet, \& Corpet, 2000; Corpet, Tache, \& Preclaire, 1997; Cohen \& Ito, 20002).

This substance could cause irritation to the skin and eyes (Science Lab, 2013a).

This substance could cause bloating, cold and flu-like symptoms (Daly, Tomlin, \& Read, 1993; Sargent et al., 1990). 


\section{Calcium Supplement}

Calcium Carbonate

Aids in the removal of surface stains and plaque on the teeth while brushing (Tahmassebi, Duggal, \& Curzon, 1994).
Risks associated with consumption of this substance include possible eye pain and irritation, coughing, and sneezing (Medline Plus, 2013).

\section{Whitening/Plaque \\ Removal}

Citric Acid

Hydrated Silica

Mica

Sodium Bicarbonate

Titanium Dioxide

Trisodium Phosphate

Aids in plaque removal (Mestres et al. 2013)

Xylitol

Xylitol aids in caries prevention (Fontana \& Gonzalez-Cabezas, 2012).

Aids in removal of dental plaque (CSPI, 2012).

Used as an abrasive to assist in plaque and stain removal (Schemehorn, Moore, \& Putt, 2011).

Used as an abrasive to assist in stain removal (Yin, 2012).

Used as an abrasive to aid in plaque and stain removal (de Araújo, Silva, de Jesus Campos, \& de Araújo, 2011).

Aids in whitening of the teeth (Julie \& Lee, 2011).

\section{Other Ingredients}

Sodium Hydroxide

Sodium hydroxide is a $\mathrm{pH}$ stabilizer (Jungbluth, Marending, De-Deus, Sener, \& Zehnder, 2011).

Aloe Vera

Glycerine
Used to reduce the amount of bacteria in the mouth (Namiranian \& Serino, 2011).

Glycerine is used to prevent toothpaste from drying out (Furness, Worthington, Bryan, Birchenough, \& McMillan, 2011; Self, 2013).
The developmental toxicity associated with chronic consumption of citric acid is not known (Science Lab, 2013b). However other risks associated with consumption of this substance include diarrhea, nausea, and stomach cramps (CSPI, 2012).

Use of silica nanoparticles in vivo poses risks for bioaccumulation (Pohaku Mitchell, Liberman, Kummel, \& Trogler, 2012).

No hazards to human health have been identified (Bernard, Osheroff, Hofman, \& Mennear, 1989).

Although rare, reactions such as dizziness, confusion, irritability, memory problems, muscle pain or aches, vomiting, or weakness can occur with excess consumption (Biosciences, 2011).

Research is mixed, however, recent work has suggested that titanium dioxide in higher concentrations may be dangerous (Julia \& Lee, 2011). Specifically, chronic health effects include possible harm to one's upper respiratory tract and lungs (Science Lab, 2013g)

Risks associated with consumption could include gastrointestinal issues (Colonial Chemical Solutions, 2010)

Research supports that xylitol is not carcinogenic (Fontana \& Gonzalez-Cabezas, 2012).

The toxicity of sodium hydroxide via toothpaste consumption is unclear, however, at high concentrations sodium hydroxide has been shown to affect the viability of esophageal cells (Malvasio, Ainoedhofer, Ackbar, Hoellwarth, \& Saxena, 2012).

Research supports that aloe vera is not toxic (Sehgal et al., 2013), however, warnings have been issued about extracts (CSPI, 2013).

Though generally found to be low-toxic, at high concentrations, glycerine could impair blood circulation (Maes et al., 2012).

Identified health risks were identified in 78.1\% $(\mathrm{n}=25)$ of these ingredients and found to range from dehydration to elevated blood sugar levels.

\section{Discussion}

The findings in this study are noteworthy for three reasons. First, the majority of all the ingredients identified in this sample have specific and known contamination risks associated with chronic consumption $(75.6 \%$ [n $=34])$. Children's fluoridated toothpastes intentionally use artificial colors, sweeteners, foam boosters, and flavorings to 
increase their appeal to young children. However, these ingredients do not contribute to the improved oral health of children. The known contamination risks, as documented in Table 1, pose a number of potential health concerns.

Second, all of the toothpaste products identified in this study contained fluoride and nearly all were flavored, presenting the risk that they could be consumed as if they were a food product. Chronic toothpaste consumption among young children is of particular concern since research documents that children under the age of six years often swallow between 25\% - 33\% of toothpaste during each brushing (Dincer, 2008). In fact, in 2011, the American Association of Poison Control Centers registered 21,513 calls for over ingestion of fluoridated toothpaste (Bronstein, Spyker, Cantilena, Rumack, \& Dart, 2012). Marketing toothpaste to children as if it is a food exacerbates this issue. Further, given that toothpaste is a product that is used daily by children, the risk of bioaccumulation stemming from chronic consumption of these toxic substances is worrying.

Third, the majority of all the unnecessary ingredients $(69.2 \%)$ were found to have known contamination risks, and half of the toothpastes in the sample contained more than one of these ingredients, further compounding the risk. It should be noted that the known contamination risks documented in this study are a heightened issue among children, given their smaller body size in comparison to adults, the way in which they metabolize exposure to chemicals, and because they are physically developing (Bearer, 1995).

In generalizing these findings, one primary limitation of this study should be considered. Specifically, that no one definition of "overconsumption" exists, therefore making it difficult to estimate the specific risk associated with a given amount of toothpaste. This inconsistency in the literature regarding definition highlights an additional area of future research and study. As described earlier, however, no amount of toothpaste is ever intended to be consumed. Therefore, we consider the chronic consumption of children's fluoridated toothpaste (swallowing any amount of toothpaste, multiple times a week and for an extended period of time) to warrant pause and consideration.

The authors recommend that the risk associated with possible chronic consumption of fluoridated toothpaste be lowered by limiting toothpaste manufacturing practices to include only those ingredients that are necessary for improved oral health and care and also only using natural flavorings when needed. Currently, there are brands of all-natural toothpastes that are available and that do not contain artificial flavorings, colorings, or sweeteners. While artificially flavored and colored toothpaste can increase positive oral health habits among children because it has appealing characteristics, there are other alternatives on the market. Dental professionals and health professionals should continue to work with parents to help encourage safe brushing, spitting, and swallowing practices among their children. Additionally, public health professionals should advocate for further regulatory scrutiny of oral health products manufactured specifically for children.

\section{Acknowledgements}

The authors would like to acknowledge Dr. Sonali Rajan, and Alexis Guinta, RDH for their contributions to this manuscript.

\section{Competing Interests Statement}

The authors declare that there is no conflict of interests regarding the publication of this paper.

\section{References}

Afflitto, J., Fakhry-Smith, S., \& Gaffar, A. (1989). Salivary and plaque triclosan levels after brushing with a $0.3 \%$ triclosan/copolymer/NAF dentifrice. American Journal of Dentistry, 2, 207-210.

American Dental Association. (2013a). Should children use fluoride toothpaste? Retrieved from http://www.ada.org/4052.aspx\#shouldchildrenuse

American Dental Association. (2013b). Toothpaste. Retrieved from http://www.ada.org/1322.aspx

Basch, C. H., \& Rajan, S. (2014). Marketing strategies and warning labels on children's toothpaste. Journal of Dental Hygiene, 88(5), 316-319.

Bearer, C. F. (1995). Environmental health hazards: How children are different from adults. The Future of Children, 11-26. http://dx.doi.org/10.2307/1602354

Becker, A., Katzen, F., Pühler, A., \& Ielpi, L. (1998). Xanthan gum biosynthesis and application: A biochemical/genetic perspective. Applied Microbiology and Biotechnology, 50(2), 145-152. http://dx.doi.org/10.1007/s002530051269

Bernard, B. K., Osheroff, M. R., Hofman, A., \& Mennear, J. H. (1989). Toxicology and carcinogenesis studies of 
dietary titanium dioxide-coated mica in male and female Fischer 344 rats. Journal of Toxicology and Environmental Health, 28(4), 415-426. http://dx.doi.org/10.1080/15287398909531361

Bhardwaj, A., \& Bhardwaj, S. V. (2011). Effectiveness of three different toothpaste formulations in reduction of plaque and gingivitis: A comparative clinical study. World Journal of Dentistry, 2, 89-92. http://dx.doi.org/10.5005/jp-journals-10015-1062

Biosciences. (2011). Sodium bicarbonate safety data sheet. Retrieved from https://media.vwr.com/stibo/hi_res/9846072.pdf

Blondeel, A., Oleffe, J., \& Achten, G. (1978). Contact allergy in 330 dermatological patients. Contact Dermatitis, 4(5), 270-276. http://dx.doi.org/10.1111/j.1600-0536.1978.tb04557.x

Boberg, J., Taxvig, C., Christiansen, S., \& Hass, U. (2010). Possible endocrine disrupting effects of parabens and $\begin{array}{llll}\text { their } \quad \text { metabolites. } & \text { Reproductive }\end{array}$ http://dx.doi.org/10.1016/j.reprotox.2010.03.011

Bronstein, A. C., Spyker, D. A., Cantilena Jr, L. R., Rumack, B. H., \& Dart, R. C. (2012). 2011 annual report of the American Association of Poison Control Centers' National Poison Data System (NPDS): 29th annual report. Clinical Toxicology, 50(10), 911-1164. http://dx.doi.org/10.3109/15563650.2012.746424

Centers for Disease Control. (2011). NIOSH pocket guide to chemical hazards. Retrieved from http://www.cdc.gov/niosh/npg/npgd0606.html

Centers for Disease Control. (2013). Community water fluoridation, FAQs for dental fluorosis. Retrieved from http://www.cdc.gov/fluoridation/safety/dental_fluorosis.htm

Center for Science in the Public Interest (CSPI). (2012). Chemical cuisine: Learn about food additives. Retrieved from https://www.cspinet.org/reports/chemcuisine.htm

Center for Science in the Public Interest (CSPI). (2013). CSPI Says Consumers Should Avoid Aloe Vera Taken Orally. Retrieved from http://www.cspinet.org/new/201308211.html

Chen, J., Zhou, X., Zhang, Y., Zi, Y., Qian, Y., Gao, H., \& Lin, S. (2012). Binding of triclosan to human serum albumin: Insight into the molecular toxicity of emerging contaminant. Environmental Science and Pollution Research, 19(7), 2528-2536. http://dx.doi.org/10.1007/s11356-012-0901-5

Cohen, S. M., \& Ito, N. (2002). A critical review of the toxicological effects of carrageenan and processed eucheuma seaweed on the gastrointestinal tract. Critical Reviews in Toxicology, 32(5), 413-444. http://dx.doi.org/10.1080/20024091064282

Colonial Chemical Solutions. (2010). Material safety data sheet: Trisodium phosphate. Retrieved from http://colonialchemicals.com/uploads/Products/Trisodium\%20Phosphate/Trisodium\%20Phosphate_MSDS. pdf

Corpet, D. E., Taché, S., \& Préclaire, M. (1997). Carrageenan given as a jelly, does not initiate, but promotes the growth of aberrant crypt foci in the rat colon. Cancer Letters, 114(1), 53-55. http://dx.doi.org/10.1016/S0304-3835(97)04624-7

Daly, J., Tomlin, J., \& Read, N. W. (1993). The effect of feeding xanthan gum on colonic function in man: Correlation with in vitro determinants of bacterial breakdown. British Journal of Nutrition, 69(03), 897-902. http://dx.doi.org/10.1079/BJN19930089

de Araújo, D. B., Silva, L. R., de Jesus Campos, E., \& de Araújo, R. P. C. (2011). In vitro study on tooth enamel lesions related to whitening dentifrice. Indian Journal of Dental Research, 22(6), 770. http://dx.doi.org/10.4103/0970-9290.94665

DeLattre, V. F. (1999). Factors contributing to adverse soft tissue reactions due to the use of tartar control toothpastes: Report of a case and literature review. Journal of Periodontology, 70(7), 803-807. http://dx.doi.org/10.1902/jop.1999.70.7.803

Delorenzo, M. E., Keller, J. M., Arthur, C. D., Finnegan, M. C., Harper, H. E., Winder, V. L., \& Zdankiewicz, D. L. (2008). Toxicity of the antimicrobial compound triclosan and formation of the metabolite methyl triclosan in estuarine systems. Environmental Toxicology, 23(2), 224-232. http://dx.doi.org/10.1002/tox.20327

DiLuccio, R. C., Hussain, M. A., CoffinBeach, D., Torosian, G., Shefter, E., \& Hurwitz, A. R. (1989). Polyvinyl alcohol-methyl acrylate copolymers as a sustained-release oral delivery system. Pharmaceutical Research, 
6(10), 844-847. http://dx.doi.org/10.1023/A:1015900303534

Dincer, E. (2008). Why do I have white spots on my front teeth? The New York State Dental Journal, 74(1), 58-60.

Duhigg, Charles. (2012). The power of habit: why we do what we do in life and business. New York: Random House.

Duke, S. A., Reading, J. P., \& Jackson, R. J. (1988). Effect of orthophosphates and citrates in fluoride toothpastes on plaque pH. Caries Research, 22(6), 350-352. http://dx.doi.org/10.1159/000261136

Dumortier, G., Grossiord, J. L., Agnely, F., \& Chaumeil, J. C. (2006). A review of poloxamer 407 pharmaceutical and pharmacological characteristics. Pharmaceutical Research, 23(12), 2709-2728. http://dx.doi.org/10.1007/s11095-006-9104-4

Environmental Working Group, (2013). D\&C red 30 lake. Retrieved from http://www.ewg.org/skindeep/ingredient/701802/D\&C_RED_30_LAKE/

Erdal, S., \& Buchanan, S. (2005). A quantitative look at fluorosis, fluoride exposure, and intake in children using a health risk assessment approach. Environmental Health Perspectives, 113(1), 111-117. http://dx.doi.org/10.1289/ehp.7077

Ethier, A. A., Muckle, G., Bastien, C., Dewailly, É., Ayotte, P., Arfken, C., ... Saint-Amour, D. (2012). Effects of environmental contaminant exposure on visual brain development: A prospective electrophysiological study in school-aged children. Neurotoxicology, 33(5), 1075-1085. http://dx.doi.org/10.1016/j.neuro.2012.05.010

Fernández-Bañares, F., Esteve, M., \& Viver, J. M. (2009). Fructose-sorbitol malabsorption. Current Gastroenterology Reports, 11(5), 368-374. http://dx.doi.org/10.1007/s11894-009-0056-9

Fitch, C., \& Keim, K. S. (2012). Position of the Academy of Nutrition and Dietetics: Use of nutritive and nonnutritive sweeteners. Journal of the Academy of Nutrition and Dietetics, 112(5), 739-758. http://dx.doi.org/10.1016/j.jand.2012.03.009

Fontana, M., \& González-Cabezas, C. (2012). Are we ready for definitive clinical guidelines on xylitol/polyol use? Advances in Dental Research, 24(2), 123-128. http://dx.doi.org/10.1177/0022034512449468

Food and Drug Administration. (2010). Overview of food ingredients, additives and colors. Retrieved from http://www.fda.gov/Food/IngredientsPackagingLabeling/FoodAdditivesIngredients/ucm094211.htm

Food and Drug Administration. (2013). Triclosan: What consumers should know. Retrieved from $\mathrm{http} / / / \mathrm{www}$. fda.gov/forconsumers/consumerupdates/ucm205999.htm

Fruijtier-Pölloth, C. (2005). Safety assessment on polyethylene glycols (PEGs) and their derivatives as used in cosmetic products. Toxicology, 214(1), 1-38. http://dx.doi.org/10.1016/j.tox.2005.06.001

Furness, S., Worthington, H. V., Bryan, G., Birchenough, S., \& McMillan, R. (2011). Interventions for the management of dry mouth: Topical therapies. Cochrane Database of Systematic Reviews, 12. http://dx.doi.org/10.1002/14651858.cd008934.pub2

Garala, K., Joshi, P., Shah, M., Ramkishan, A., \& Patel, J. (2013). Formulation and evaluation of periodontal in situ gel. International Journal of Pharmaceutical Investigation, 3(1), 29. http://dx.doi.org/10.4103/2230-973X.108961

Giacaman, R. A., Campos, P., Muñoz-Sandoval, C., \& Castro, R. J. (2013). Cariogenic potential of commercial sweeteners in an experimental biofilm caries model on enamel. Archives of Oral Biology, 58(9), 1116-1122. http://dx.doi.org/10.1016/j.archoralbio.2013.03.005

Golden, R., Gandy, J., \& Vollmer, G. (2005). A review of the endocrine activity of parabens and implications for potential risks to human health. Critical Reviews in Toxicology, 35(5), 435-458. http://dx.doi.org/10.1080/10408440490920104

Griffiths, J. C. (2005). Coloring foods and beverages. Food Technology, 59(5), 38-44.

He, T., Baker, R., Bartizek, R. D., Biesbrock, A. R., Chaves, E., \& Terézhalmy, G. (2007). Extrinsic stain removal efficacy of a stannous fluoride dentifrice with sodium hexametaphosphate. Journal of Clinical Dentistry, 18(1), 7.

Heifetz, S. B., \& Horowitz, H. S. (1986). Amounts of fluoride in self-administered dental products: Safety considerations for children. Pediatrics, 77(6), 876-882. 
International Programme on Chemical Safety, World Health Organization. (1999). Safety evaluation of certain food additives: WHO food additives series: 42. Retrieved from http://www.inchem.org/documents/jecfa/jecmono/v042je04.htm

Jacob, S. E., \& Amini, S. (2008). Cocamidopropyl betaine. Dermatitis, 19(3), 157-160.

Johnson, P. I., Koustas, E., Vesterinen, H. M., Sutton, P., Atchley, D. S., Kim, A. N., ... Zeise, L. (2016). Application of the Navigation Guide systematic review methodology to the evidence for developmental and reproductive toxicity of triclosan. Environment International. http://dx.doi.org/10.1016/j.envint.2016.03.009

Julia, X. Y., \& Li, T. H. (2011). Distinct biological effects of different nanoparticles commonly used in cosmetics and medicine coatings. Cell \& Bioscience, $1(1), 1$.

Jungbluth, H., Marending, M., De-Deus, G., Sener, B., \& Zehnder, M. (2011). Stabilizing sodium hypochlorite at high pH: Effects on soft tissue and dentin. Journal of Endodontics, 37(5), 693-696. http://dx.doi.org/10.1016/j.joen.2011.02.019

Kobylewski, S., \& Jacobson, M. F. (2010). Food dyes: A rainbow of risks. Center for Science in the Public Interest.

Kraivaphan, P., Amornchat, C., \& Triratana, T. (2013). Determination of plaque viability following a single brushing with commercial toothpastes. Journal of Clinical Dentistry, 24(10), 20-24.

Lanigan, R. S. (2000). Final report on the safety assessment of sodium metaphosphate, sodium trimetaphosphate, and sodium hexametaphosphate. International Journal of Toxicology, 20, 75-89.

Lewis, R. J. (1996). Sax's dangerous properties of industrial materials (9th ed.) New York, NY: Van Nostrand Reinhold.

Llena, C., Forner, L., \& Vento, C. (2009). Anticalculus efficacy of a new dentifrice. Quintessence International, 40(6).

Luo, H., Wilber, W., \& Guo, J. H. (2004). Multivalent ion compatible carbomer formulations. U.S. Patent Application No. 10/766,274. Retrieved from http://patentscope.wipo.int/search/en/WO2004069170

Maes, J., Verlooy, L., Buenafe, O. E., de Witte, P. A., Esguerra, C. V., \& Crawford, A. D. (2012). Evaluation of 14 organic solvents and carriers for screening applications in zebrafish embryos and larvae. PloS one, 7(10), e43850. http://dx.doi.org/10.1371/journal.pone.0043850

Malvasio, V., Ainoedhofer, H., Ackbar, R., Hoellwarth, M. E., \& Saxena, A. K. (2012). Effects of sodium hydroxide exposure on esophageal epithelial cells in an in vitro ovine model: Implications for esophagus $\begin{array}{lllll}\text { tissue engineering. Journal of Pediatric Surgery, } & \text { 47(5), }\end{array}$ http://dx.doi.org/10.1016/j.jpedsurg.2012.01.033

Medline Plus. (2013). Calcium carbonate overdose. Retrieved from http://www.nlm.nih.gov/medlineplus/ency/article/002605.htm

Mestres, G., Abdolhosseini, M., Bowles, W., Huang, S. H., Aparicio, C., Gorr, S. U., \& Ginebra, M. P. (2013). Antimicrobial properties and dentin bonding strength of magnesium phosphate cements. Acta Biomaterialia, 9(9), 8384-8393. http://dx.doi.org/10.1016/j.actbio.2013.05.032

Moreau, J., \& Kaplan, B. (2013). Toothpaste-associated labial allergic contact dermatitis. Allergy, 68, 598-598).

Munoz, F. J., Bellido, J., Moyano, J. C., Alvarez, M., \& Fonseca, J. L. (1996). Perioral contact urticaria from sodium benzoate in a toothpaste. Contact Dermatitis, 35(1), 51-51. http://dx.doi.org/10.1111/j.1600-0536.1996.tb02272.x

Nair, B. (2000). Final report on the safety assessment of benzyl alcohol, benzoic acid, and sodium benzoate. International Journal of Toxicology, 20, 23-50.

Namiranian, H., \& Serino, G. (2011). The effect of a toothpaste containing aloe vera on established gingivitis. Swedish Dental Journal, 36(4), 179-185.

National Center for Biotechnology Information. (2013). Propylparaben: Compound summary. Retrieved from http://pubchem.ncbi.nlm.nih.gov/summary/summary.cgi?cid=7175

National Institute of Environmental Health Sciences. (2000). D\&C red no. 27/D\&C red no. 28. Retrieved from http://ntp.niehs.nih.gov/ntp/htdocs/Chem_Background/ExSumPdf/RedDyes_508.pdf 
Nicole, W. (2013). Secret ingredients: Who knows what's in your food? Environmental Health Perspectives, 121(6), A126-33. http://dx.doi.org/10.1289/ehp.121-a126

Podariu, A. C., Galuscan, A., \& Rosianu, R. S. (2009). The innocuity of triclosan. A review. Timisoara Medical Journal, 60(1), 90-3.

Pohaku Mitchell, K. K., Liberman, A., Kummel, A. C., \& Trogler, W. C. (2012). Iron (III)-doped, silica nanoshells: A biodegradable form of silica. Journal of the American Chemical Society, 134(34), 13997-14003. http://dx.doi.org/10.1021/ja3036114

Ramirez, A. (1990). All About/Toothpaste; Growth Is Glacial, but the Market Is Big, and So Is the Gross. New York Times, Retrieved from http://www.nytimes.com/1990/05/13/business/all-about-toothpaste-growthis-glacial-but-the-market-is-big-and-so-is-the-gross.html?pagewanted=all

Rock, W. P. (1994). Young children and fluoride toothpaste. British Dental Journal, 177(1), 17-20. http://dx.doi.org/10.1038/sj.bdj.4808490

Sainio, E. L., \& Kanerva, L. (1995). Contact allergens in toothpastes and a review of their hypersensitivity. Contact Dermatitis, 33(2), 100-105. http://dx.doi.org/10.1111/j.1600-0536.1995.tb00509.x

Sargent, E. V., Adolph, J., Clemmons, M. K., Kirk, G. D., Pena, B. M., \& Fedoruk, M. J. (1990). Evaluation of flu-like symptoms in workers handling xanthan gum powder. Journal of Occupational and Environmental Medicine, 32(7), 625-630. http://dx.doi.org/10.1097/00043764-199007000-00014

Schemehorn, B. R., Moore, M. H., \& Putt, M. S. (2011). Abrasion, polishing, and stain removal characteristics of various commercial dentifrices in vitro. Journal of Clinical Dentistry, 22(1), 11.

Schrankel, K. R. (2004). Safety evaluation of food flavorings. Toxicology, 198(1), 203-211. http://dx.doi.org/10.1016/j.tox.2004.01.027

Science Lab. (2013a). Material safety data sheet: Carboxymethyl cellulose sodium. Retrieved from http://www.sciencelab.com/msds.php?msdsId=9923316

Science Lab. (2013b). Material safety data sheet: Citric acid. Retrieved from http://www.sciencelab.com/msds.php?msdsId=9923494

Science Lab. (2013c). Material safety data sheet: D \& C red \#33 MSDS. Retrieved from http://www.sciencelab.com/msds.php?msdsId=9923654

Science Lab. (2013d). Material safety data sheet: Polyethyene glycol 1450 MSDS. Retrieved from http://www.sciencelab.com/msds.php?msdsId=9926624

Science Lab. (2013e). Material safety data sheet: Sodium benzoate. Retrieved from https://www.sciencelab.com/msds.php?msdsId=9927413

Science Lab. (2013f). Material safety data sheet: Sodium phosphate MSDS. Retrieved from http://www.sciencelab.com/msds.php?msdsId=9925023

Science Lab. (2013g). Material safety data sheet: Titanium dioxide MSDS. Retrieved from http://www.sciencelab.com/msds.php?msdsId=9925268

Schnuch, A., Lessmann, H., Geier, J., \& Uter, W. (2011). Is cocamidopropyl betaine a contact allergen? Analysis of network data and short review of the literature. Contact Dermatitis, 64(4), 203-211. http://dx.doi.org/10.1111/j.1600-0536.2010.01863.x

Sehgal, I., Winters, W. D., Scott, M., David, A., Gillis, G., Stoufflet, T., ... Kousoulas, K. (2013). Toxicologic assessment of a commercial decolorized whole leaf aloe vera juice, lily of the desert filtered whole leaf juice with aloesorb. Journal of Toxicology, 2013. http://dx.doi.org/10.1155/2013/802453

Self, R. L. (2013). Direct analysis in real time-mass spectrometry (DART-MS) for rapid qualitative screening of toxic glycols in glycerin-containing products. Journal of Pharmaceutical and Biomedical Analysis, 80, 155-158. http://dx.doi.org/10.1016/j.jpba.2013.02.037

Skaare, A., Kjærheim, V., Barkvoll, P., \& Rølla, G. (1997). Skin reactions and irritation potential of four commercial toothpastes. Acta Odontologica Scandinavica, 55(2), 133-136. http://dx.doi.org/10.3109/00016359709115405

Smith, R. L., Cohen, S. M., Doull, J., Feron, V. J., Goodman, J. I., Marnett, L. J., ... Adams, T. B. (2005). Criteria for the safety evaluation of flavoring substances: The Expert Panel of the Flavor and Extract Manufacturers Association. Food and Chemical Toxicology, 43(8), 1141-1177. http://dx.doi.org/10.1016/j.fct.2004.11.012 
Soffritti, M., Padovani, M., Tibaldi, E., Falcioni, L., Manservisi, F., Lauriola, M., ... Belpoggi, F. (2016). Sucralose administered in feed, beginning prenatally through lifespan, induces hematopoietic neoplasias in male swiss mice. International Journal of Occupational and Environmental Health. Retreived from http://www.tandfonline.com/doi/abs/10.1080/10773525.2015.1106075

Soni, M. G., Burdock, G. A., Taylor, S. L., \& Greenberg, N. A. (2001). Safety assessment of propyl paraben: A review of the published literature. Food and Chemical Toxicology, 39(6), 513-532. http://dx.doi.org/10.1016/S0278-6915(00)00162-9

Spectrum Laboratory. (2007). Material safety data sheet: Poloxamer 407. Retrieved from http://phm.utoronto.ca/ ddubins/MSDS/Poloxamer_407_MSDS.pdf

Tache, S., Peiffer, G., Millet, A. S., \& Corpet, D. E. (2000). Carrageenan gel and aberrant crypt foci in the colon of conventional and human flora-associated rats. Nutrition and Cancer, 37(2), 193-198. http://dx.doi.org/10.1207/S15327914NC372_12

Tahmassebi, J., Duggal, M. S., \& Curzon, M. E. J. (1994). Effect of a calcium carbonate-based toothpaste with $0.3 \%$ triclosan on $\mathrm{pH}$ changes in dental plaque in vivo. Caries Research, 28(4), 272-276. http://dx.doi.org/10.1159/000261985

Ten Cate, J. M. (2013). Contemporary perspective on the use of fluoride products in caries prevention. British Dental Journal, 214(4), 161-167. http://dx.doi.org/10.1038/sj.bdj.2013.162

Vie, K., Pons-Guiraud, A., Dupuy, P., \& Maibach, H. (2000). Tolerance profile of a sterile moisturizer and moisturizing cleanser in irritated and sensitive skin. American Journal of Contact Dermatitis, 11(3), 161-164. http://dx.doi.org/10.1053/ajcd.2000.7183

Warren, A, Benseler, V., Cogger, V.C., Bertolino, P. \& Le Couteur, D. G. (2011). Impact of Poloxamer 407 on the ultrastructure of the liver and evidence for clearance by extensive endothelial Kupffer cell endocytosis. Toxicologic Pathology, 39(2), 390-397. http://dx.doi.org/10.1177/0192623310394212

Wenande, E. C., Skov, P. S., Mosbech, H., Poulsen, L. K., \& Garvey, L. H. (2013). Inhibition of polyethylene glycol-induced histamine release by monomeric ethylene and diethylene glycol: A case of probable polyethylene glycol allergy. Journal of Allergy and Clinical Immunology, 131(5), 1425. http://dx.doi.org/10.1016/j.jaci.2012.09.037

Wilhelm, K. P., Surber, C., \& Maibach, H. I. (1991). Effect of sodium lauryl sulfate-Induced skin irritation on in vivo percutaneous penetration of four drugs. Journal of Investigative Dermatology, 97(5), 927-932. http://dx.doi.org/10.1111/1523-1747.ep12491710

Winston, J. L., Fiedler, S. K., Schiff, T., \& Baker, R. A. (2007). An anticalculus dentifrice with sodium hexametaphosphate and stannous fluoride: A six-month study of efficacy. Journal of Contemporary Dental Practice, 8(5), 1-8.

Yin, L. (2012). Property-process relations in simulated clinical abrasive adjusting of dental ceramics. Journal of the Mechanical Behavior of Biomedical Materials, 16, 55-65. http://dx.doi.org/10.1016/j.jmbbm.2012.07.011

\section{Copyrights}

Copyright for this article is retained by the author(s), with first publication rights granted to the journal.

This is an open-access article distributed under the terms and conditions of the Creative Commons Attribution license (http://creativecommons.org/licenses/by/4.0/). 